\title{
The Effect of Talent Management on the Performance of Educational Employee in Higher Education Institutions
}

\author{
Dyah Purwaningsih ${ }^{1, *}$ Tjutju Yuniarsih ${ }^{2,}$ Disman $^{3,}$ Janah Sojanah $^{4}$ \\ ${ }^{1}$ Universitas Pendidikan Indonesia \\ ${ }^{2}$ Universitas Pendidikan Indonesia \\ ${ }^{3}$ Universitas Pendidikan Indonesia \\ ${ }^{4}$ Universitas Pendidikan Indonesia \\ *Corresponding author.Email:dyahsidik@student.upi.edu
}

\begin{abstract}
The purpose of this study is to find out the effect of talent management on the performance of educational employee in higher education. The approach used for this research was a quantitative approach. The sample used in this study was 61 talented educational employees from higher education in West-Java and DKI Jaya provinces. Data analysis techniques used in the study were Partial Least Square Structural Equation Modeling (PLS -SEM) with Smart PLS software. The results showed that the application of talent management in higher education had a positive and moderate effect on the performance of educational employee.
\end{abstract}

Keywords: Educational Employee Performance, Talent Management.

\section{INTRODUCTION}

Higher education has a very important role in the nation's development. Many parties, including alumni, parents, taxpayers, businessmen, students, accreditation agencies, governments, and non-governmental organizations expect a good quality from higher education institutions [1]. This is because the results of the education process in higher education determine the quality of graduates who will work and contribute to the nation and state. Reference [2] state that in general most universities formulate their quality assurance systems according to the national standards that exist in their countries and are based on their own needs. Unfortunately, the quality of most universities in Indonesia compared to universities abroad is still very low as reported by QS World University Rankings in 2018 which lists 959 top universities in the world and is based on opinion more than 75,000 academics, 40,000 companies and 12.3 million research papers and 75.1 million citations. In 2017 , only 10 tertiary institutions in Indonesia were included in the list of the 1000 best tertiary institutions according to the QS World University Rankings. The lowest was Universitas Indonesia (UI) at the 277th, followed by Institute Teknologi Bandung (ITB) at the 331st, which experienced a decline in 2018 where UI placed 292nd, ITB placed 359th and Universitas Gajah Mada (UGM) got higher position from 400th to 391st. The components used by QS World University Rankings as the assessment points included academic reputation, the reputation of graduates in the world of work, the number of international students, and the number of research publications and journals. Even so, [3] argues that higher education institutions should not be too influenced by world university rankings because it is feared that they will not focus on improving the quality of their educational institutions.

This research is based on the desire to improve the quality of universities in the country. This is because the quality of most of higher education institutions in the country is still far from satisfactory. This can be seen from the ranking of Indonesian university in the world. Universities in Indonesia face challenges to be better because of the fierce competition among universities both inside and outside the nation. One of the ways to increase its competitiveness is by improving the quality of university and its employees. A research conducted by 
[2] on 297 higher education institutions in more than 20 countries in Europe showed that the quality of higher education institutions was strongly influenced by teaching and learning activities, curriculum development and student service, followed by organizational management and research.

Both assessments conducted by international institutions and the Indonesian Ministry of Education and Culture indicated that the employee performance component plays the most dominant role for the quality of a university, particularly the performance of educators. However, improving the quality of higher education can have an impact on systems, institutions, or individuals in higher education. The impact on the individual level, for example, they have to prioritize their research or teaching objectives, getting more workload to meet bureaucratic needs which can affect the behavior and work of academics [4]. Based on the above considerations, it is necessary to conduct a study to find out what aspects that can improve the performance of employees, so that the quality of higher education will improve.

In order to maintain and improve the achievements of tertiary institutions, the leaders and management must be able to continue to manage employees who have high competence and good performance. One of the ways to obtain, develop, and maintain employees who have high competence and good performance is through talent management [5]. Talent Management (TM) is basically a process carried out by the organization to answer those needs. TM does not only talk about developing and managing employee careers, but also how organizations can attract and manage their chosen human resources. On a broader scope, TM also means how an organization manages its resources starting from the recruitment process, employee placement, performance appraisal, training and career development, until the employee leaves the company (employee separation), so that ultimately the goals of the organization can be achieved [6].

The issue of talent management originally came from the private sector, but later developed and also benefited the public sector [7]. Talent management is important and is taken seriously by the many organizations [8]. However, it is still difficult to find research concerning the effect of talent management on talented employees working in higher education institutions. Even if there is, then the research is only limited to the implementation of talent management in general in tertiary institutions and has not focused on talented employees. Therefore, it is important to conduct research entitled: The Effect of Talent Management on the Performance of Educational Employee in Higher Education Institutions.

\subsection{Talent management}

The definition of talent according to [9] is a human who wants to be maintained by the company because of its strengths. In addition, talent management can become a comprehensive strategic approach to identify, evaluate, develop and allocated talented human resources to help the activities in achieving the best performance and organization [10].

Noting the above explanation, broadly the management of human resources referred to talent management can begin from the recruitment process, employee placement, performance appraisal, training and career development, until the employee leaves the company [6].

The results that companies can get by using talent management strategies are filling top management positions with quality people, so the company does not need to doubt the performance of employees who will be appointed as part of the company's top positions [9]. This relates to the theory issued by Pratt [11] explaining that investment in the form of talent management can produce quality workers and produce work with high quality performance. Thus, it can be seen that there was a significant relationship between talent management and employee performance. Based on research by [5], talent management had a positive influence on faculty performance in private universities.

\subsection{Employee performance}

Research from [12] showed that talent management had a positive effect on job involvement and employee performance. Employee performance is the real behavior shown by employees as a result of work produced by employees in accordance with their role in the company. According to [13] there are several dimensions in performance including quality, quantity, and interpersonal impact. Quality is the closeness of the measurement results with the real value, while quantity is the amount formed from something, and the last is the interpersonal impact which is an opportunity for someone to develop a sense of mutual respect and cooperation with others. Referring to [14], employee performance measurement can be done. Based on the research results conducted by [15], the work environment had a significant effect on the performance of University employees.

\section{METHODS}

The approach used in this research was a quantitative approach. The sample used in this study was 61 talented employees from various universities in West Java and DKI Jaya provinces. Data analysis techniques used in this research were Partial Least Square Structural Equation Modeling (PLS SEM) with Smart PLS software. The 
latent variables used in this research were Talent Management (TM) as an exogenous variable and Performance $(\mathrm{P})$ as an endogenous variable. Indicators and symbols for talent management are shown in Table 1. Indicators and symbols for employee performance are shown in Table 2.

Table 1. Indicators and symbols for talent management

\begin{tabular}{|l|l|}
\hline \multicolumn{1}{|c|}{ Indicators } & Symbols \\
\hline Recruitment of talented employees & TM1 \\
\hline Competitive tests & TM2 \\
\hline Identify talent pool & TM3 \\
\hline Management is responsible for the talent pool & TM4 \\
\hline Opportunities for training and development & TM5 \\
\hline Distribution of talented employees & TM6 \\
\hline Efforts to keep talented employees & TM7 \\
\hline Compensation management & TM8 \\
\hline Career management & TM9 \\
\hline
\end{tabular}

Dimensions of talent management are acquisition of talent, identification, talent development, spread of talent, retention, compensation, and career planning.

Table 2. Indicators and symbols for employee performance

\begin{tabular}{|l|l|}
\hline \multicolumn{1}{|c|}{ Indicators } & Symbols \\
\hline Quality of work & $\mathrm{P} 1$ \\
\hline Work quantity & $\mathrm{P} 2$ \\
\hline Job knowledge & $\mathrm{P} 3$ \\
\hline Expertise & $\mathrm{P} 4$ \\
\hline Cooperation & $\mathrm{P} 5$ \\
\hline Communication & $\mathrm{P} 6$ \\
\hline Obedience & $\mathrm{P} 7$ \\
\hline Initiative & $\mathrm{P} 8$ \\
\hline Innovative ideas & $\mathrm{P} 9$ \\
\hline Mastery of new technologies & $\mathrm{P} 10$ \\
\hline Adaptation to environmental & $\mathrm{P} 11$ \\
\hline Manage work stress & $\mathrm{P} 12$ \\
\hline Creative problem solving & $\mathrm{P} 13$ \\
\hline
\end{tabular}

Dimensions of performance are task performance, contextual performance, and adaptive performance.

\section{RESULTS AND DISCUSSION}

\subsection{Model measurement (outer model)}

Based on the validity test, all indicators were considered valid because the value was above 0.5 . According to [16] an indicator is considered valid if it has a correlation value above 0.70 . However, loading 0.50 to 0.60 is still acceptable by looking at the output correlation between the indicator and its construct. Based on the validity test, all indicators were considered valid because the results of the loading factor on the outer loading PLS Algorithm as well as the results of PLS bootstrapping showed values above 0.5 (see Figure 1).

This value is a cross loading factor value which is useful for knowing whether the construct has adequate discriminant, in which the loading value of the intended construct must be greater than the value of loading with other constructs. From the test it was found that the construct indicator correlation had a higher value compared to the indicator correlation with other constructs, so it is said that the construct had a high discriminant validity.

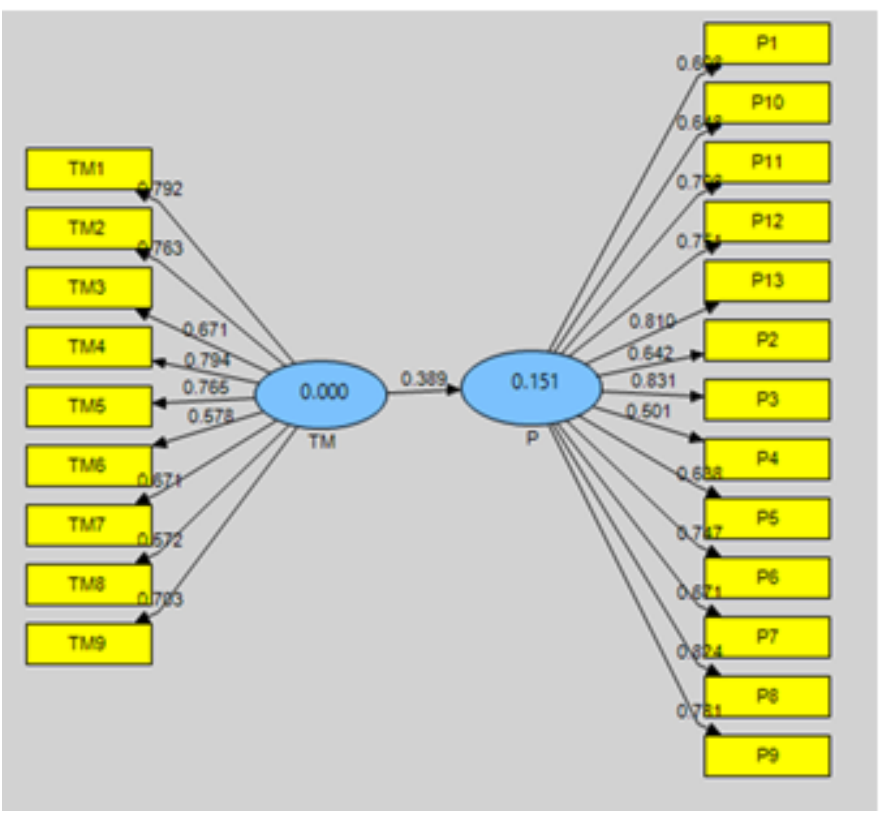

Figure 1. PLS Algoritma Result.

Reliability test was done by looking at the composite reliability value of the indicator block that measured the construct. Composite reliability for Performance was 0.929 and composite reliability for Talent management was 0.898 . According to [16] the results of composite reliability shows a satisfactory value if it is above 0.7 .

\subsection{Structural test model (inner model)}

From the PLS bootstrapping test results, it was obtained r-square value of 0.151 . This value shows the ability of independent variables to explain the dependent variable. The higher the $\mathrm{R}$-square value, the greater the ability of the independent variable to explain the dependent variable. According to [16], the value of $\mathrm{R}$ square is 0.67 (strong), 0.33 (moderate) and 0.19 (weak).

Estimate for Path Coefficients was used to evaluate the relationship between latent constructs as hypothesized in the study. Based on PLS testing, it was found that TM had a positive influence on job satisfaction by 0.389 . The $\mathrm{H} 1$ hypothesis was accepted because the statistical $\mathrm{T}$ value was 2,680 which mean it was greater than $2.01 \mathrm{t}$ table values so it can be said that TM was able to explain a significant effect on performance.

\section{CONCLUSIONS}

Based on the research results and discussion, it can be concluded that $\mathrm{H} 1$ hypothesis was accepted because the statistical $\mathrm{T}$ value was greater than the $\mathrm{t}$ table. Thus, it can 
be said that talent management was able to explain a significant effect on performance. The application of talent management in higher education had a strong influence on moderate performance, which is in accordance with the statement of [5].

The results also showed that the factors most influenced by the application of talent management in tertiary institutions were job knowledge and creative problem solving from employees.

\section{ACKNOWLEDGMENT}

I would like to thank LPDP (Lembaga Pengelola Dana Pendidikan) for sponsoring my web-presentation in Bandung. My compliments to School of Post Graduates, Indonesia University of Education which provided us with great support.

\section{REFERENCES}

[1] S. Marshall, "Internal and external stakeholders in higher education," in Shaping the University of the Future, 2018, pp. 77-102.

[2] K. Alzafari and J. Ursin, "Implementation of quality assurance standards in European higher education: does context matter?," Qual. High. Educ., vol. 25, no. 1, pp. 58-75, 2019.

[3] K. M. Hauptman, "Discourses on quality and quality assurance in higher education from the perspective of global university rankings.," Qual. Assur. Educ., vol. 28, no. 1, 2020.

[4] Y. P. Hsu, "The evolution of quality assurance in higher education in Taiwan: The changes and the effects at different levels.," High. Educ. Policy, vol. 32, no. 3, 2019.

[5] B. Priyadarshini and R. Sinha, "Impact of talent management on employee performance: A study of private universities in Bengaluru.," Our Herit. J., vol. 22, no. 3, 2020.
[6] R. J. Lewis, R.E. and Heckman, "Talent Management: A critical review," Hum. Resour. Manag. Rev., vol. 16, pp. 139-154, 2006.

[7] F. Kravariti and K. Johnston, "Talent management: a critical literature review and research agenda for public sector human resource management.," Public Manag. Rev., vol. 22, no. 1, 2020.

[8] Smilansky, "Developing Executive Talent. Metode Efektif untuk Mengidentifikasi dan Mengembangkan Pemimpin dalam Perusahaan". Jakarta: PPM, 2008.

[9] A. Pella, D. A. \& Inayati, "Manajemen talenta: mengembangkan SDM untuk mencapai pertumbuhan dan kinerja prima", Jakarta: PT Gramedia Pustaka, 2011.

[10] Z. Muhyi, Herwan Abdul., Muttaqqin and Nurmalasari, HR Plan \& Strategy. Jakarta: Swadaya Group, 2016.

[11] B. Bethke-Langenegger, P., Mahler \& P. Staffelbach, "Effectiveness of talent management strategies," Eur. J. Int. Manag., vol. 5, no. 5, pp. 524-539, 2011.

[12] S. Sopiah, D. T. Kurniawan, E. Nora, and N. B. S., "Does talent management affect employee performance?: The moderating role of work engagement.," J. Asian Financ. Econ. Bus., vol. 7, no. 7,2020 .

[13] J. E. A. Bernardin, H. J. and Russell, Human Resource Management: An Experiential Approach. Singapore: Mc-Graw Hill Publ., 1998.

[14] L. Koopmans, "Measuring individual work performance - identifying and selection indicators," A J. Prev. Assess. Rehabil., vol. 45, 2013.

[15] L. T. Puryantoro and Rasidi, "Work environment: How is it influenced on employee performance?," Int. J. Sci. Technol. Manag., vol. 1, no. 4, 2020.

[16] I. Ghozali, SEM Metode Alternatif dengan PLS. Semarang: BP Universitas Diponegoro, 2008. 